\title{
Potato (Solanum tuberosum L.) Yield, NPK Concentration and Uptake as Influenced by Variable Levels of Drip Irrigation and Fertigation
}

\author{
Shakshi Mankotia* and Sanjay Sharma \\ Department of Soil Science, College of Agriculture, CSK Himachal Pradesh Agricultural \\ University, Palampur (176062), India \\ *Corresponding author
}

\section{A B S T R A C T}

Ke y w o r d s
potato yield, drip
irrigation and
fertigation, NPK
concentration and
uptake

Field experiment was conducted at the experimental farm of Department of Soil Science, College of Agriculture, CSK Himachal Pradesh Krishi Vishvavidyalaya, Palampur, to study the effect of drip irrigation and fertigation levels on yield, NPK concentration and their uptake by potato. Experiment was laid out in randomized block design (RBD) with treatments including three drip irrigation levels viz., 0.4 PE, 0.6 PE and $0.8 \mathrm{PE}$ corresponding to 40, 60 and 80 per cent of cumulative pan evaporation, respectively, three fertigation levels viz., $50 \%$ RDF, $75 \%$ RDF and $100 \%$ RDF equivalent to 50,75 and 100 per cent of recommended dose of NPK, respectively and RP i.e. recommended practice (recommended dose of fertilizers through conventional methods and 6 flood irrigations of $50 \mathrm{~mm}$ each). The results revealed that drip irrigation levels did not have significant effect on tuber yield and NPK contents. Total NPK uptake by potato was influenced by irrigation levels but the differences between the higher irrigation levels of $0.6 \mathrm{PE}$ and $0.8 \mathrm{PE}$ were not significant. Fertigation level of $75 \%$ RDF was statistically at par with $100 \%$ RDF but significantly better than $50 \%$ RDF with respect to yield and nutrients uptake. Fertigation level of $75 \%$ RDF gave significantly higher marketable tuber yield $\left(21.97 \mathrm{t} \mathrm{ha}^{-1}\right)$ and it was 22 per cent higher than that obtained with $50 \%$ RDF $\left(18.01 \mathrm{t} \mathrm{ha}^{-1}\right)$. No improvement in yield was obtained with $100 \% \mathrm{RDF}$ over $75 \%$ RDF. Also, Drip irrigation and fertigation was better than the recommended practice as combination of irrigation level of $0.6 \mathrm{PE}$ and $75 \% \mathrm{RDF}$ recorded similar yield, thereby saving 25 per cent of NPK.

\section{Introduction}

Potato (Solanum tuberosum L.) is the third most consumed crop globally behind rice and wheat. It is a versatile crop that can be cultivated in diverse environment. Potato, a carbohydrate rich food highly popular worldwide, can be important crop in solving food and nutritional security problems. Freshly harvested potato tubers contain about
80 per cent water and 20 per cent dry matter of which 70 per cent is starch. On the dry weight basis, the protein content of potato is similar to that of cereals and is very high in comparison with other root and tuber crops.

Potato is a short duration, high yielding and nutrients exhaustive tuber crop. There are number of factors that play a crucial role in deciding the growth and yield of potato, 
however, irrigation and fertilization are the most predominating among them. Improper irrigation management practices not only waste the expensive and scarce water resources but also reduce the tuber yield and quality. Hence, it is possible to increase the production of potato by adopting wellscheduled irrigation programs throughout the growing season.

Fertigation of crops with nitrogen and potassium fertilizers is quite common but keeping in view the phosphorus fixation problem in acid soils, the application of phosphorus through drip fertigation in acidic soils may prove beneficial owing to its localized application in the vicinity of root zone rendering less area for fixation.

But, there is very limited information on drip irrigation and NPK fertigation, particularly for potato grown in acid Alfisols of Himachal Pradesh. Moreover, water application based on cumulative pan evaporation during a specified interval is one of the most important irrigation approaches for quantifying the amount of irrigation water.

\section{Materials and Methods}

\section{Location and site characteristics}

A field experiment was conducted at the experimental farm of CSK Himachal Pradesh Krishi Vishvavidyalaya, Palampur. The experimental farm is situated at $32^{\circ} 6^{\prime} \mathrm{N}$ latitude and $76^{\circ} 3$ ' E longitude at an altitude of about $1290 \mathrm{~m}$ above mean sea level. The site lies in the Palam valley of Kangra district representing mid hill wet temperate zone (Zone 2.2) of Himachal Pradesh. Taxonomically, the soils of study area fall under order Alfisol and sub-group Typic Hapludalf. These soils have originated from rocks like slates, phyllites, quartzites, schists and gneisses.

\section{Experimental details}

The field experiment on potato was laid out in randomized block design (RBD) with ten treatments, each replicated three times. The details of treatments are as follows:

\section{Treatments}

\section{Irrigation levels 3}

0.4 PE Drip irrigation equivalent to 40 per cent of cumulative pan evaporation) 0.6 PE Drip irrigation equivalent to 60 per cent of cumulative pan evaporation)

0.8 PE Drip irrigation equivalent to 80 per cent of cumulative pan evaporation)

\section{Fertigation levels 3}

$50 \%$ RDF $\quad 50$ per cent of recommended dose of fertilizer

$75 \%$ RDF 75 per cent of recommended dose of fertilizer

$100 \%$ RDF 100 per cent of recommended dose of fertilizer

$\mathbf{R P}$

Recommended package of practices

\section{Total number of Treatments}

$3 * 3+1(10)$

The recommended dose of fertilizers (RDF) for potato was $\mathrm{N}, \mathrm{P}_{2} \mathrm{O}_{5}$ and $\mathrm{K}_{2} \mathrm{O}$ were 120,80 and $60 \mathrm{~kg} \mathrm{ha}^{-1}$, respectively. The irrigations were applied through online drip system on alternate days for each treatment. Fertigation was done as per treatments using urea and water soluble fertilizers 17:44:00 and 00:00:50. Fertigation was started after complete emergence of the crop. Fertigation with 17:44:00 and 00:00:50 was completed in 5 splits whereas, urea was applied in 10 splits. 
The fertigation were applied at an interval of 7 days. In the last treatment i.e. RP, recommended dose of fertilizers was applied through urea, single super phosphate and muriate of potash. Half of the nitrogen dose (60 $\mathrm{kg} \mathrm{N} \mathrm{ha}^{-1}$ ) and full dose of phosphorus and potassium was applied in the RP treatment at the time of sowing. The remaining dose of nitrogen in this treatment was applied at the time of earthing up. Six irrigations @ $50 \mathrm{~mm}$ water per irrigation were applied during the crop period.

\section{Results and Discussion}

\section{Yield}

The data pertaining to the effect of drip irrigation and fertigation levels on marketable tuber, haulm and total yield are given in Table 1. A perusal of the data revealed that varying drip irrigation levels from $0.4 \mathrm{PE}$ to $0.8 \mathrm{PE}$ did not affect the marketable tuber, haulm and total yield of potato significantly. The reason for non-significant effect of irrigation levels on tuber haulm and total yield may be ascribed to the fact that soil moisture contents under these levels, though increased with irrigation level but no moisture stress was observed at any level during the crop growth as the soil moisture contents were nearby field capacity of the soil and there was ample availability of water for the crop growth.

Secondly, the relative leaf water contents recorded at tuber initiation and bulking stages also indicate that there was no water stress even at lower level of irrigation i.e. 0.4 PE. Therefore, the crop under varying levels of irrigation was able to utilize the nutrients properly for growth and development of tubers. Similar results have been reported by different workers for various crops under almost same set of conditions where irrigation levels did not influence the crop yield (Kapoor et al., 2013 and Kapoor, 2016).
As regards the effect of fertigation levels, the highest tuber yield (21.97 $\mathrm{t} \mathrm{ha}^{-1}$ ) and total yield $\left(25.41 \mathrm{t} \mathrm{ha} \mathrm{ha}^{-1}\right)$ were obtained with fertigation level of $75 \%$ RDF whereas, haulm yield was highest $\left(3.67 \mathrm{t} \mathrm{ha}^{-1}\right)$ at $100 \% \mathrm{RDF}$. There was significant increase in the tuber haulm and total yield of potato with increase in fertigation levels.

The marketable tuber, haulm and total yield obtained at $50 \%$ RDF were 18.01, 3.27 and $21.27 \mathrm{t} \mathrm{ha}^{-1}$, respectively which increased to $21.97,3.44$ and $25.41 \mathrm{t} \mathrm{ha}^{-1}$, respectively at 75 $\%$ RDF, the corresponding increases being about 22, 5.5 and 19 per cent, respectively. Further increase in fertigation level to $100 \%$ RDF significantly increased the marketable tuber, haulm and total yield over $50 \%$ RDF by about $16.7,12.6$ and 16.1 per cent, respectively but the tuber and total yields. The data further revealed that fertigation level of $75 \%$ RDFwas statistically at par with $100 \%$ $\mathrm{RDF}$ in respect of tuber and total yield.

Similar results were reported by Patel and Patel (2001) where they opined that higher rate of NPK provided better growth, development and translocation of photosynthates to tubers which might have resulted into higher yield of tubers. Similar findings were reported by Datta and Chakraborty (1995), Singh et al., (2010), Kapoor et al., (2013) and Kapoor (2016).

No significant difference in tuber yield (17.37 $\mathrm{t} \mathrm{ha}^{-1}$ ) obtained between the recommended practice involving surface irrigation and recommended fertilization (RP) and overall mean of different drip irrigation and fertigation combinations termed as others $(20$. $\left.33 \mathrm{t} \mathrm{ha}^{-1}\right)$. However, haulm yield (3.46 q ha-1) and total yield $\left(23.79 \mathrm{q} \mathrm{ha}^{-1}\right)$ were significantly higher in others in comparison to recommended practice. This clearly established the benefit of drip irrigation coupled with fertigation over the 
recommended practice since similar tuber yield could be realized by consuming less water and nutrients. Interaction between fertigation and drip irrigation levels on potato yield was not found significant.

\section{Nutrient concentration}

\section{Nitrogen}

Table 2 contains the data with respect to the $\mathrm{N}$ concentration as influenced by different treatments. Varying irrigation levels from 0.4 $\mathrm{PE}$ to $0.8 \mathrm{PE}$ did not affect nitrogen concentration in potato tubers and haulms, whereas fertigation levels increased the nitrogen concentration in potato tubers and haulms significantly. Highest $\mathrm{N}$ concentration in tubers $(1.75 \%)$ and haulms $(2.88 \%)$ was obtained with fertigation level of 100 per cent recommended dose of NPK which was about 10.1 per cent and 6.7 per cent higher than that obtained with fertigation level of 50 per cent of recommended dose of NPK, respectively. The data further revealed that fertigation level of 100 per cent of recommended dose of NPK was statistically at par with 75 per cent of recommended dose of NPK with respect to N concentration in tubers. Similar results have been reported by Sharma and Sood (2002) where they recorded higher $\mathrm{N}$ content which was attributed to an increase in root proliferation through the action of nitrogen on cellular activities and translocation of certain growth stimulating compounds to roots, which in turn helped in better tuber growth and uptake of nutrients.

The nitrogen concentration in tuber $(1.69 \%)$ and haulm $(2.79 \%)$ was significantly higher under the overall mean of fertigation and irrigation levels (others) over recommended practice (RP) which recorded 1.60 and 2.64 percent nitrogen in tubers and haulm, respectively. This might be due to better availability of nutrients through fertigation over soil applied nutrients. Interaction between fertigation and drip irrigation levels on $\mathrm{N}$ content in potato was not found significant.

\section{Phosphorous}

Table 3 contains the data with respect to the $P$ concentration as influenced by different treatments. The data presented in table 3 indicated that varying irrigation levels from 0.4 PE to 0.8 PE did not affect phosphorus concentration in potato tubers and haulms, however, fertigation levels influenced the phosphorus concentration in potato tubers and haulms significantly. Among different fertigation levels, highest phosphorus concentration in tuber $(0.261 \%)$ and haulm $(0.273 \%)$ was obtained with fertigation level of 100 per cent of recommended dose of NPK in comparison to 75 per cent of recommended dose of NPK $(0.240$ and $0.25 \%$ in tubers and haulms, respectively) and 50 per cent of recommended dose of NPK (0.226 and $0.217 \%$ in tubers and haulms, respectively). Adequate supply of $\mathrm{P}$ along with $\mathrm{N}$ and $\mathrm{K}$ through fertigation near the root system might have led to development of extensive root system for translocation of nutrients for better use of soil moisture and nutrients resulting in higher concentration of $\mathrm{P}$ in tubers as well as haulm. Similar results have been reported by Chaurasia and Singh (1993)and Patel et al., (2012).

Phosphorus concentration in tubers $(0.242$ per cent) and haulms (0.247) was significantly higher under overall mean of irrigation and fertigation levels (others) as compared to recommended practices which recorded 0.211 and .213 per cent $\mathrm{P}$ in tubers and haulm, respectively. The reasons for this might be the same as explained for $\mathrm{N}$ concentration. Interaction between fertigation and drip irrigation levels on $\mathrm{P}$ content in potato was not significant. 


\section{Potassium}

A reference to the data in Table 4 on potassium concentration as influenced by different treatments indicated that varying irrigation levels from $0.4 \mathrm{PE}$ to $0.8 \mathrm{PE}$ did not affect potassium concentration in potato tubers, however, fertigation levels influenced the potassium concentration in potato tuber significantly. Highest potassium concentration in tubers $(1.42 \%)$ was obtained with 100 per cent of recommended dose of NPK which was about 5.2 percent and 8.4 per cent higher than that obtained with 75per cent of recommended dose of NPK $(1.35 \%)$ and 50 per cent of recommended dose of NPK $(1.31 \%)$, respectively.

Regarding $\mathrm{K}$ concentration in haulm, irrigation levels as well as fertigation levels influenced the potassium concentration significantly. Highest potassium concentration $(1.91 \%)$ was obtained with irrigation level of $0.8 \mathrm{PE}$ which was about 3.8 per cent higher than that obtained with irrigation depth of $0.4 \mathrm{PE}$. The data showed that irrigation level of $0.8 \mathrm{PE}$ was statistically at par with $0.6 \mathrm{PE}$.

Among fertigation levels, the highest potassium concentration (1.97 \%) was obtained with fertigation level of 100 per cent of recommended dose of NPK which was about 5.9 percent and 10.1 per cent higher than that obtained with 75per cent of recommended dose of NPK and 50 per cent of recommended dose of NPK. The findings of Ibrikci and Buyuk (2002) also support our data where the irrigation levels significantly affected leaf $\mathrm{N}, \mathrm{P}$ and $\mathrm{K}$ contents in drip fertigated plants. As regards the comparison of overall mean of irrigation and fertigation levels (others) with recommended practice (RP), potassium concentration in tubers and haulms (was significantly higher under former $(1.36 \%$ and $1.87 \%)$ as compared to later which recorded 1.26 per cent and 1.72 per cent $\mathrm{K}$ in tubers and haulm, respectively. Interaction between fertigation and drip irrigation levels on $\mathrm{K}$ content in potato was not found significant. Better availability of nutrients through water soluble fertilizers applied through fertigation nearby the root zone and proper moisture in soil throughout the growth period of potato might have led to higher uptake of nutrients including potassium.

\section{Nutrient uptake}

\section{Nitrogen}

The data with respect to nitrogen uptake as influenced by different irrigation and fertigation levels have been given in Table 5 . Varying irrigation levels from $0.4 \mathrm{PE}$ to 0.8 PE did not affect nitrogen uptake by potato tubers, whereas nitrogen uptake by haulm was significantly higher in irrigation level of 0.8 PE $\left(24.0 \mathrm{~kg} \mathrm{ha}^{-1}\right)$ in comparison to $0.4 \mathrm{PE}$ $\left(22.4 \mathrm{~kg} \mathrm{ha}^{-1}\right)$. Similarly, total (haulm +tuber) uptake by potato was significantly higher in irrigation level of $0.8 \mathrm{PE}\left(89.2 \mathrm{~kg} \mathrm{ha}^{-1}\right)$ in comparison to $0.4 \mathrm{PE}$ (79.1 $\left.\mathrm{kg} \mathrm{ha}^{-1}\right)$. This may be due to comparatively higher yield and $\mathrm{N}$ content obtained under $0.8 \mathrm{PE}$ in comparison to $0.4 \mathrm{PE}$ irrigation levelas uptake depends upon the product of yield and nutrient concentration. However, there was no significant difference between $0.6 \mathrm{PE}$ and 0.8 PE. Proper moisture during the plant growth promote the translocation of available and applied nutrients from soil, which in turn are better utilized by the plant resulting in higher nitrogen uptake in haulms (Dubey et al., 1998).

Fertigation levels influenced $\mathrm{N}$ uptake significantly. The increase in fertigation from 50 per cent to 75 per cent of recommended dose of NPK resulted in significant increase of 31.9 per cent in nitrogen uptake by tubers. 
Further increase in fertigation from 75 per cent to 100 per cent of recommended dose of NPK did not increase the $\mathrm{N}$ uptake of tubers significantly.

Total uptake by potato was also influenced by fertigation levels in similar way. Total $\mathrm{N}$ uptake of $\mathrm{N}$ was significantly higher in 100 per cent recommended dose of NPK $(91.6 \mathrm{~kg}$ $\left.\mathrm{ha}^{-1}\right)$ as compared to 50 per cent recommended dose of NPK $\left(72.8 \mathrm{~kg} \mathrm{ha}^{-1}\right)$. The fertigation level of 75per cent recommended dose increased the total nitrogen uptake by 25.3 per cent over 50per cent recommended dose of NPK. Fertigation level of 75 per cent recommended dose of NPK was however, statistically at par with 100 per cent recommended dose of NPK.

As regards $\mathrm{N}$ uptake by haulm, there was consistent increase upto 100 per cent recommended dose of NPK. The N uptake by haulm at 100 per cent recommended dose of NPK was $25.4 \mathrm{~kg} \mathrm{ha}^{-1}$ whereas, it was significantly lower under 75 per cent recommended dose of NPK $\left(21.2 \mathrm{~kg} \mathrm{ha}^{-1}\right)$.

As regards the comparison of overall mean of all fertigation and irrigation levels (others) with recommended practice (RP), it was observed that uptake by tuber, haulm and total uptake by potato was significantly higher in former $\left(61.9,23.2\right.$ and $85.2 \mathrm{~kg} \mathrm{ha}^{-1}$, respectively) than the $\mathrm{RP}$ which recorded $\mathrm{N}$ uptake of 50.0, 19.7 and $69.7 \mathrm{~kg} \mathrm{ha}^{-1}$ by tuber, haulm and total (tuber+haulm), respectively. The interaction between fertigation and irrigation levels on $\mathrm{N}$ uptake by potato was not significant.

The higher uptake of $\mathrm{N}$ with increase in fertigation levels is as per expectation due to increase in yield and $\mathrm{N}$ concentration observed in the present study. Similar results were reported by Shanmugasundaram and Savithri (2000) where they opined that even nitrogen applied at higher level found to be beneficial since hydrolysis of urea made the nutrients easily available to the plant roots resulting in higher dry matter accumulation. Also, similar results reported by Jannat (2007), Fahmy et al., (2008), Kapoor et al., (2013) and Kapoor (2016).

\section{Phosphorus}

The data pertaining to phosphorus uptake as affected by different treatments have been presented in Table 6. Among different irrigation levels, highest $\mathrm{P}$ uptake of 9.51, 2.14 and $11.65 \mathrm{~kg} \mathrm{ha}^{-1}$ by tubers, haulm and haulm+tuber (total) was obtained with irrigation level of 0.8 PE. These uptake values recorded under $0.8 \mathrm{PE}$ were about 20.2, 10.9 and 18.4 per cent higher than that obtained with irrigation level of $0.4 \mathrm{PE}$ where the $\mathrm{P}$ uptake by tubers, haulm and haulm+tuber (total) were $7.91,1.93$ and $9.84 \mathrm{~kg} \mathrm{ha}^{-1}$, respectively. The data showed that irrigation level of 0.6 PE was statistically at par with irrigation level of 0.8 PE. Similar results were reported by Sadawarti et al., (2013) where they revealed that water is essential for increasing the uptake of phosphorus. Also, similar results were reported by Patel et al., (2012) where they revealed that higher uptake of phosphorous might be due to sound rootsoil relation, which provides rapid diffusion of ions by reducing the path length of ion movement on one hand and increase in elongation, turgidity and number of root hairs which ultimately, boost the uptake of phosphorus on other hand. Further, the maintenance of relatively higher moisture content and high frequency of irrigation might have also lead to the greater mobility of $\mathrm{P}$ and availability to plants (Bacon and Davey, 1982).

Among different fertigation levels, highest $\mathrm{P}$ uptake by tubers, haulm and tuber + haulm (total) was obtained with fertigation level of 
100 per cent recommended dose of NPK, the values being 9.87, 2.41 and $12.27 \mathrm{~kg} \mathrm{ha}^{-1}$, respectively. These were about 34.1, 41.8 and 35.4 per cent higher than that obtained with 50 per cent recommended dose of NPK where $\mathrm{P}$ uptake by tubers, haulm and tuber + haulm (total) amounted to $7.36,1.70$ and $9.06 \mathrm{~kg}$ ha 1 , respectively. The data showed that fertigation level of 100per cent recommended dose of NPK was statistically at par with fertigation level of 75 per cent recommended dose of NPK with respect to $\mathrm{P}$ uptake by potato. Overall mean of fertigation and irrigation levels (others) exhibited significantly higher P uptake by tubers, haulm and tuber+haulm (total)corresponding to 8.92, 2.06 and $10.97 \mathrm{~kg} \mathrm{ha}^{-1}$, respectively in comparison to that recorded under the recommended practice (RP) where these values were $6.60,1.59$ and $8.18 \mathrm{~kg} \mathrm{ha}^{-1}$, respectively. The interaction between fertigation and irrigation levels on $\mathrm{P}$ uptake by potato was not significant.

The higher $\mathrm{P}$ uptake with increase in fertigation levels was obvious as higher levels of $\mathrm{P}$ provided ample nutrients to the plants which might have led to better root development and root proliferation for uptake of the nutrients. The higher $\mathrm{P}$ uptake under overall effect of fertigation and irrigation levels may also be due to the fact that phosphorus was applied through fertigation in five splits which increased its availability to the plants where as in recommended practice phosphorus was applied in the soil as basal which might have been subjected to fixation in the acid soil under experimentation.

\section{Potassium}

The data pertaining to potassium uptake as affected by different treatments have been presented in Table 7 . There was no significant effect of irrigation levels on potassium uptake by tubers. However, uptakes of potassium by haulm and tuber+haulm (total) (16.3 and 68.2 $\mathrm{kg} \mathrm{ha}^{-1}$, respectively) under irrigation level of $0.8 \mathrm{PE}$ were significantly higher by about 9.4 and 12.5 per cent in comparison to that obtained under irrigation level of 0.4 PE (14.9 and $60.6 \mathrm{~kg} \mathrm{ha}^{-1}$, respectively). However, there was no significant difference between irrigation levels of 0.6 PE and 0.8 PE. These results are in conformity with the findings of Patel et al., (2012) who ascribed this to increased movement of potassium under adequate soil moisture conditions leading to higher uptake of potash in haulms.

As regards the potassium uptake under different fertigation levels, $\mathrm{K}$ uptake by tubers, haulm and tuber + haulm(total) under fertigation level of 50 per cent recommended dose of NPK amounted to 42.5, 14.0 and 56.4 $\mathrm{kg} \mathrm{ha}^{-1}$, respectively. The respective values under fertigation level of 75 percent of RDF were $53.5,15.4$ and $68.9 \mathrm{~kg} \mathrm{ha}^{-1}$ and that under fertigation level of 100 per cent of RDF were $53.7,17.3$ and $71.0 \mathrm{~kg} \mathrm{ha}^{-1}$, respectively. The uptake of potassium by tubers and tubers+haulm (total) at 100\% RDF was higher by about 26.4 per cent and 25.9 per cent over50\% RDF. Fertigation levels $75 \%$ RDF and $100 \%$ RDF were statistically at par Whereas, $\mathrm{K}$ uptake by haulm was significantly higher in $100 \%$ RDF $(17.3 \mathrm{~kg}$ $\mathrm{ha}^{-1)}$ as compared to $75 \% \operatorname{RDF}\left(15.4 \mathrm{~kg} \mathrm{ha}^{-1}\right)$ and $50 \%$ RDF $\left(14.0 \mathrm{~kg} \mathrm{ha}{ }^{-1}\right)$. Better availability of nutrients at higher levels of fertigation resulted in higher $\mathrm{K}$ content as well as the yield in potato, which ultimately resulted in higher K uptake. Similar results have been reported for different crops by many workers (Kapoor et al., 2013 and Kapoor, 2016).

The comparison of overall mean of fertigation and irrigation combinations (others) with recommended practice (RP) revealed that $\mathrm{K}$ uptakes by tuber, haulm and tuber + haulm(total) were significantly higher under 
former (49.9, 15.6 and $65.5 \mathrm{~kg} \mathrm{ha}{ }^{-1}$, respectively) than later $(29.4,12.8$ and 52.2 $\mathrm{kg} \mathrm{ha}^{-1}$, respectively). As per expectation, the uniform delivery of nutrients near the root zone following fertigation proved beneficial in comparison to soil application of nutrients. The interaction between fertigation and irrigation levels was not significant for $K$ uptake by tuber, haulm and tuber + haulm of potato.

Table.1 Effect of drip irrigation and fertigation levels on tuber, haulm and total yield $\left(\mathrm{t} \mathrm{ha}{ }^{-1}\right)$

\begin{tabular}{|l|c|c|c|}
\hline Treatments & Tuber yield & Haulm yield & Total yield \\
\hline Irrigation level & \multicolumn{3}{|c|}{} \\
\hline 0.4 PE & 18.93 & 3.37 & 22.30 \\
\hline 0.6 PE & 20.93 & 3.47 & 24.40 \\
\hline 0.8 PE & 21.13 & 3.53 & 24.67 \\
\hline CD (P=0.05) & NS & NS & NS \\
\hline Fertigation level & & & \\
\hline 50 \% RDF & 18.01 & 3.26 & 21.27 \\
\hline $\mathbf{7 5} \%$ RDF & 21.97 & 3.44 & 25.41 \\
\hline 100 \% RDF & 21.02 & 3.67 & 24.69 \\
\hline CD (P=0.05) & 2.35 & 0.14 & 2.31 \\
\hline Recommended practices (RP) vs others & & \\
\hline RP & 17.37 & 3.11 & 20.48 \\
\hline Others & 20.33 & 3.46 & 23.79 \\
\hline CD (P=0.05) & NS & 0.18 & 2.98 \\
\hline
\end{tabular}

Table.2 Effect of drip irrigation and fertigation levels on nitrogen concentration in potato

\begin{tabular}{|l|c|c|}
\hline Treatments & \multicolumn{2}{|c|}{ Nitrogen (\%) } \\
\hline \multicolumn{1}{|l|}{ Tuber } & Haulm \\
\hline Irrigation level & & \\
\hline 0.4 PE & 1.66 & 2.76 \\
\hline 0.6 PE & 1.69 & 2.79 \\
\hline 0.8 PE & 1.70 & 2.83 \\
\hline CD (P=0.05) & NS & NS \\
\hline Fertigation level & & \\
\hline 50 \% RDF & 1.59 & 2.70 \\
\hline 75 \% RDF & 1.72 & 2.80 \\
\hline 100 \% RDF & 1.75 & 2.88 \\
\hline CD (P=0.05) & 0.06 & 0.06 \\
\hline Recommended practices (RP) vs others \\
\hline RP & 1.60 & 2.64 \\
\hline Others & 1.69 & 2.79 \\
\hline CD (P=0.05) & 0.07 & 0.08 \\
\hline
\end{tabular}


Table.3 Effect of drip irrigation and fertigation levels on phosphorus concentration in potato

\begin{tabular}{|c|c|c|}
\hline \multirow[t]{2}{*}{ Treatments } & \multicolumn{2}{|c|}{ Phosphorus (\%) } \\
\hline & Tuber & Haulm \\
\hline \multicolumn{3}{|c|}{ Irrigation level } \\
\hline 0.4 PE & 0.231 & 0.238 \\
\hline $0.6 \mathrm{PE}$ & 0.246 & 0.251 \\
\hline $0.8 \mathrm{PE}$ & 0.250 & 0.252 \\
\hline $\mathrm{CD}(\mathrm{P}=\mathbf{0 . 0 5})$ & NS & NS \\
\hline \multicolumn{3}{|c|}{ Fertigation level } \\
\hline $50 \%$ RDF & 0.226 & 0.217 \\
\hline $75 \%$ RDF & 0.240 & 0.250 \\
\hline $100 \%$ RDF & 0.261 & 0.273 \\
\hline $\mathrm{CD}(\mathrm{P}=\mathbf{0 . 0 5})$ & 0.016 & 0.014 \\
\hline \multicolumn{3}{|c|}{ Recommended practices (RP) vs others } \\
\hline $\mathbf{R P}$ & 0.211 & 0.213 \\
\hline Others & 0.242 & 0.247 \\
\hline $\mathrm{CD}(\mathrm{P}=\mathbf{0 . 0 5})$ & 0.021 & 0.018 \\
\hline
\end{tabular}

Table.4 Effect of drip irrigation and fertigation levels on potassium concentration in potato

\begin{tabular}{|l|c|c|}
\hline \multicolumn{2}{|c|}{ Treatments } & \multicolumn{2}{c|}{ Potassium (\%) } \\
\hline Irrigation level & & Haulm \\
\hline 0.4 PE & 1.34 & 1.84 \\
\hline 0.6 PE & 1.38 & 1.87 \\
\hline 0.8 PE & 1.36 & 1.91 \\
\hline CD (P=0.05) & NS & 0.06 \\
\hline Fertigation level & & \\
\hline 50 \% RDF & 1.31 & 1.79 \\
\hline 75 \% RDF & 1.35 & 1.86 \\
\hline $\mathbf{1 0 0} \%$ RDF & 1.42 & 1.97 \\
\hline CD (P=0.05) & 0.03 & 0.06 \\
\hline Recommended practices (RP) vs others \\
\hline RP & 1.26 & 1.72 \\
\hline Others & 1.36 & 1.87 \\
\hline CD (P=0.05) & 0.04 & 0.08 \\
\hline
\end{tabular}


Table.5 Effect of drip irrigation and fertigation levels on nitrogen uptake by potato

\begin{tabular}{|l|c|c|c|}
\hline Treatments & \multicolumn{3}{|c|}{ N uptake ( kg ha-1) } \\
\hline & Tuber & Haulm & $\begin{array}{c}\text { Total } \\
\text { (tuber+haulm) }\end{array}$ \\
\hline Irrigation level & & \\
\hline 0.4 PE & 56.8 & 22.4 & 79.2 \\
\hline 0.6 PE & 63.9 & 23.3 & 87.2 \\
\hline 0.8 PE & 65.2 & 24.0 & 89.2 \\
\hline CD (P=0.05) & NS & 1.1 & 7.2 \\
\hline Fertigation level & & & \\
\hline 50 \% RDF & 51.6 & 21.2 & 72.8 \\
\hline 75 \% RDF & 68.1 & 23.1 & 91.2 \\
\hline 100 \% RDF & 66.2 & 25.4 & 91.6 \\
\hline CD (P=0.05) & 7.5 & 1.1 & 7.2 \\
\hline Recommended practices (RP) vs others \\
\hline RP & 50.0 & 19.7 & 69.7 \\
\hline Others & 61.9 & 23.2 & 85.1 \\
\hline CD (P=0.05) & 9.7 & 1.1 & 9.4 \\
\hline
\end{tabular}

Table.6 Effect of drip irrigation and fertigation levels on phosphorus uptake by potato

\begin{tabular}{|c|c|c|c|}
\hline \multirow[t]{2}{*}{ Treatments } & \multicolumn{3}{|c|}{ P uptake $\left(\mathrm{kg} \mathrm{ha}^{-1}\right)$} \\
\hline & Tuber & Haulm & $\begin{array}{l}\text { Total (tuber + } \\
\text { haulm) }\end{array}$ \\
\hline \multicolumn{4}{|c|}{ Irrigation level } \\
\hline $0.4 \mathrm{PE}$ & 7.91 & 1.93 & 9.84 \\
\hline 0.6 PE & 9.33 & 2.10 & 11.44 \\
\hline $0.8 \mathrm{PE}$ & 9.51 & 2.14 & 11.65 \\
\hline $\mathrm{CD}(\mathrm{P}=\mathbf{0 . 0 5})$ & 1.24 & 0.13 & 1.29 \\
\hline \multicolumn{4}{|c|}{ Fertigation level } \\
\hline $50 \%$ RDF & 7.36 & 1.70 & 9.06 \\
\hline $75 \%$ RDF & 9.52 & 2.07 & 11.59 \\
\hline $100 \%$ RDF & 9.87 & 2.41 & 12.27 \\
\hline $\mathrm{CD}(\mathrm{P}=\mathbf{0 . 0 5})$ & 1.24 & 0.13 & 1.29 \\
\hline \multicolumn{4}{|c|}{ Recommended practices (RP) vs others } \\
\hline $\mathbf{R P}$ & 6.60 & 1.59 & 8.18 \\
\hline Others & 8.92 & 2.06 & 10.97 \\
\hline $\mathrm{CD}(\mathrm{P}=\mathbf{0 . 0 5})$ & 1.60 & 0.17 & 1.67 \\
\hline
\end{tabular}


Table.7 Effect of drip irrigation and fertigation levels on potassium uptake by potato

\begin{tabular}{|l|c|c|c|}
\hline \multicolumn{3}{|c|}{ Treatments } & \multicolumn{3}{|c|}{ K uptake ( kg ha' } \\
\hline & Tuber & Haulm & $\begin{array}{c}\text { Total } \\
\text { (tuber+haulm) }\end{array}$ \\
\hline Irrigation level & & & \\
\hline 0.4 PE & 45.7 & 14.9 & 60.6 \\
\hline 0.6 PE & 52.0 & 15.6 & 67.6 \\
\hline 0.8 PE & 51.9 & 16.3 & 68.2 \\
\hline CD (P=0.05) & NS & 0.9 & 5.9 \\
\hline Fertigation level & & & \\
\hline 50 \% RDF & 42.5 & 14.0 & 56.4 \\
\hline $\mathbf{7 5}$ \% RDF & 53.5 & 15.4 & 68.9 \\
\hline 100 \% RDF & 53.7 & 17.3 & 71.0 \\
\hline CD (P=0.05) & 6.1 & 0.9 & 5.9 \\
\hline Recommended practices (RP) vs others \\
\hline RP & 39.4 & 12.8 & 52.2 \\
\hline Others & 49.9 & 15.6 & 65.5 \\
\hline CD (P=0.05) & 7.9 & 1.1 & 7.6 \\
\hline
\end{tabular}

Varying irrigation levels from $0.4 \mathrm{PE}$ to 0.8 PE did not affect tuber, haulm and total yield of potato, whereas fertigation levels influenced the tuber, haulm and total yield significantly. The highest tuber yield $(21.97 \mathrm{t}$ $\left.\mathrm{ha}^{-1}\right)$ and total yield $\left(25.41 \mathrm{t} \mathrm{ha}{ }^{-1}\right)$ were obtained with fertigation level of $75 \%$ RDF.The marketable tuber and total yield increased by about 22and 19 per cent, respectively with the fertigation level of $75 \%$ RDFin comparison to 50\% RDF. The overall mean tuber yield from different drip irrigation and fertigation combinations (others) was statistically at par with recommended practice.

The concentration of $\mathrm{N}, \mathrm{P}$ and $\mathrm{K}$ in potato tubers and haulm, by and large remained unaffected. However, their concentration in tubers and haulm, in general, increased with increase in the fertigation levels. The recommended practice in general, recorded lower contents of N, P and $\mathrm{K}$ in tubers as well as haulm in comparison to the overall mean of irrigation and fertigation combinations. The $\mathrm{N}$ and $\mathrm{K}$ uptake by potato tubers was not affected significantly by drip irrigation levels, however, $\mathrm{P}$ uptake by tubers was more at irrigation level of $0.8 \mathrm{PE}$ in comparison to $0.4 \mathrm{PE}$ though it was at par with 0.6PE. The total uptake of $\mathrm{N}, \mathrm{P}$ and $\mathrm{K}$ by potato was significantly higher at $0.8 \mathrm{PE}$ irrigation level in comparison to $0.4 \mathrm{PE}$.

Among different fertigation levels $\mathrm{N}, \mathrm{P}$ and $\mathrm{K}$ uptake by tubers as well as total uptake by potato was significantly higher in 75 per cent of recommended dose of NPK in comparison to 50 per cent of recommended dose of NPK. There was no significant difference between 75 per cent of recommended dose of NPK and 100 per cent of recommended dose of NPK in respect of uptake of $\mathrm{N}, \mathrm{P}$ and $\mathrm{K}$ by tubers as well as the total uptake. In the comparison between 'recommended practice' and overall mean of irrigation and fertigation levels 
(others), significantly higher uptake of $\mathrm{N}, \mathrm{P}$ and $\mathrm{K}$ by potato tubers as well as total uptake by potato was observed in 'others'.

The results of our investigation suggested that drip irrigation levels did not have significant effect on tuber yield and NPK contents and thereby lowest level of drip irrigation based on 40 per cent of cummulative pan evaporation was as effective as the highest level based on 80 per cent of drip irrigation.

By and large, though total NPK uptake by potato was influenced by irrigation levels, the differences between the higher irrigation levels of $0.6 \mathrm{PE}$ and $0.8 \mathrm{PE}$ were not significant. Fertigation with 75 per cent recommended dose of NPK has been found to be statistically at par with 100 per cent recommended dose of fertilizers with respect to yield and nutrients uptake.

\section{References}

Bacon, P.E. and Davey, B.G. 1982. Nutrient availability under trickle irrigation. I. Distribution of water and Bray no. 1 phosphate.Soil Science Society of American Journal, 46: 981-98.

Chaurasia, S.N.S. and Singh, K.P. 1993. Effects of nitrogen levels and haulms cutting dates on nutrient concentration and uptake in different plant parts of potato. Journal of Indian Potato Association,20(2): 169-171.

Datta, T. and Chakraborty, T. 1995. Effect of organic manures and Subabul leaf mulching under varying levels of fertility on growth and yield of potato and weed biomass. Indian Journal of Agronomy,40(1): 140-142.

Dubey, Y.P., Kaistha, B.P. and Bhardwaj, S.K. 1998. Response of potato to irrigation and nitrogen in Lahaul valley of Himachal Pradesh. Indian Journal of Agricultural Sciences, 68(3): 174-175.
Fahmy, S.H., Sharifi, M. and Hann, S. 2008. Pulp Fiber Residue and Supplemental Irrigation on Yield and Nutrient Uptake of Potato. Journal of Plant Nutrition, 31: 716-730.

Ibrikci Guler, S. and Buyuk, H. 2002. Yield and elemental composition of cucumber as affected by drip and furrow irrigation. Acta horticulturae, 571: 5157.

Janat, M. 2007. Efficiency of nitrogen fertilizer for potato under fertigation utilizing a nitrogen tracer technique. Communications in Soil Science and Plant Analysis, 38: 2401-2422.

Kapoor, R. 2016. Effect of drip irrigation on soil-plant water dynamics, nutrient use and productivity of capsicum and broccoli under varying NPK fertigation in an acid alfisol. Ph.D. Thesis, p 197.CSK Himachal Pradesh Krishi Vishvavidyalaya, Palampur, India.

Kapoor, R., Sandal, S.K., Sharma Sanjay, K., Kumar, A. and Saroch, K. 2013. Effect of varying drip irrigation levels and NPK fertigation on soil water dynamics, productivity and water use efficiency of cauliflower (Brassica oleracea var. Botrytis) in wet temperate zone of Himachal Pradesh. Indian Journal of Soil Conservation,42: 249-254.

Patel, D.K., Patel, B.M., Patel, P.T., Patel, D.M. and Patel, B.J. 2012. Influence of irrigation methods along with nitrogen and potassium management on yield and nutrient uptake by potatoes. Agricultural Science Digest, 32(1): 3842.

Patel, J.C. and Patel, B.K. 2001. Response of potato to $\mathrm{N}$ fertilizer under trickle and furrow irrigation. Indian Journal of Potato Association 28 (2-4): 195-200

Sadawarti, M.J., Singh, S.P., Kumar, V. and Lal, S.S. 2013. Effect of mulching and irrigation scheduling on potato cultivar Kufri Chipsona-1 in central India. 
Potato Journal, 40(1): 65-71.

Shanmugasundaram, R. and Savithri, P. 2000. Effect of various $\mathrm{N}$ levels with organics and amendments on $\mathrm{N}$ content and yield of potato in Western Ghats and Tamilnadu. Journal of Indian Potato Association, 27 (3-4): 127-131.

Sharma, R.C and Sood, M.C. 2002. N and K interaction on the tuber yield, quality and organic carbon status of Shimla soils. In Potato, Global Research and Development, Volume II, 843-851.

Singh, N., Sood, M.C. and Singh, S.P. 2010. Optimizing irrigation water and nutrient requirement of potato (Solanum tuberosum L.) under drip fertigation. Progressive Agriculture, 10(1): 192195.

\section{How to cite this article:}

Shakshi Mankotia and Sanjay Sharma. 2020. Potato (Solanum tuberosum L.) Yield, NPK Concentration and Uptake as Influenced by Variable Levels of Drip Irrigation and Fertigation. Int.J.Curr.Microbiol.App.Sci. 9(05): 1277-1289. doi: https://doi.org/10.20546/ijcmas.2020.905.142 